\title{
Manganese(III) Porphyrin-Catalyzed Dehydrogenation of Alcohols to form Imines, Tertiary Amines and Quinolines
}

\author{
Azizi, Kobra; Akrami, Sedigheh; Madsen, Robert
}

Published in:

Chemistry - A European Journal

Link to article, DOI:

10.1002/chem.201900737

Publication date:

2019

Document Version

Peer reviewed version

Link back to DTU Orbit

Citation (APA):

Azizi, K., Akrami, S., \& Madsen, R. (2019). Manganese(III) Porphyrin-Catalyzed Dehydrogenation of Alcohols to form Imines, Tertiary Amines and Quinolines. Chemistry - A European Journal, 25(25), 6439-6446.

https://doi.org/10.1002/chem.201900737

\section{General rights}

Copyright and moral rights for the publications made accessible in the public portal are retained by the authors and/or other copyright owners and it is a condition of accessing publications that users recognise and abide by the legal requirements associated with these rights.

- Users may download and print one copy of any publication from the public portal for the purpose of private study or research.

- You may not further distribute the material or use it for any profit-making activity or commercial gain

- You may freely distribute the URL identifying the publication in the public portal

If you believe that this document breaches copyright please contact us providing details, and we will remove access to the work immediately and investigate your claim 


\section{CHEMISTRY A European Journal}

\section{Accepted Article}

Title: Manganese(III) Porphyrin-Catalyzed Dehydrogenation of Alcohols to form Imines, Tertiary Amines and Quinolines

Authors: Kobra Azizi, Sedigheh Akrami, and Robert Madsen

This manuscript has been accepted after peer review and appears as an Accepted Article online prior to editing, proofing, and formal publication of the final Version of Record (VoR). This work is currently citable by using the Digital Object Identifier (DOI) given below. The VoR will be published online in Early View as soon as possible and may be different to this Accepted Article as a result of editing. Readers should obtain the VoR from the journal website shown below when it is published to ensure accuracy of information. The authors are responsible for the content of this Accepted Article.

To be cited as: Chem. Eur. J. 10.1002/chem.201900737

Link to VoR: http://dx.doi.org/10.1002/chem.201900737 


\title{
Manganese(III) Porphyrin-Catalyzed Dehydrogenation of Alcohols to form Imines, Tertiary Amines and Quinolines
}

\author{
Kobra Azizi, Sedigheh Akrami and Robert Madsen*[a]
}

\begin{abstract}
Manganese(III) porphyrin chloride complexes have been developed for the first time as catalysts for the acceptorless dehydrogenative coupling of alcohols and amines. The reaction has been applied to the direct synthesis of imines, tertiary amines and quinolines where only hydrogen gas and/or water are formed as the byproduct(s). The mechanism is believed to involve the formation of a manganese(III) alkoxide complex which degrades into the aldehyde and a manganese(III) hydride species. The latter reacts with the alcohol to form hydrogen gas and thereby regenerates the alkoxide complex.
\end{abstract}

\section{Introduction}

Since the turn of the millennium, significant efforts have been devoted to the development of acceptorless dehydrogenative reactions with alcohols. ${ }^{[1]}$ In these transformations, a metal catalyst mediates the release of hydrogen gas to form the corresponding carbonyl compound, which can then undergo subsequent reactions in the same pot to generate other functional groups such as amines, imines, amides, carboxylic acids and esters. The transformations are usually catalyzed by complexes of precious metals where especially ruthenium and iridium compounds have been widely employed. ${ }^{[1]}$ In recent years, however, complexes based on the Earth-abundant metals iron, cobalt and manganese have surfaced as a new type of catalysts for the acceptorless dehydrogenations. ${ }^{[2]}$

In fact, the first manganese complex was presented in $2016^{[3]}$ and since then many manganese-based catalysts have been developed for both the dehydrogenation ${ }^{[2 a-d, 4]}$ and the reverse hydrogenation reaction. ${ }^{[2 a-d, 5]}$ With one exception, ${ }^{[6]}$ although, they are all manganese(I) complexes stabilized by $\mathrm{CO}$ ligands which are not inexpensive since they are prepared from the costly carbonyl complex $\mathrm{Mn}_{2}(\mathrm{CO})_{10}$. Thus, it would be highly desirable to identify manganese complexes in the more common oxidation states for these dehydrogenative reactions.

Very recently, we presented the first manganese(III) complex for the acceptorless dehydrogenation of alcohols and elucidated the mechanism (Scheme 1). ${ }^{[6]}$ Notably, it is a salen complex, which is a known catalytic motif in organic chemistry, but for different reactions. The mechanism was investigated by experimental and theoretical methods and the reaction was

[a] Dr. K. Azizi, S. Akrami, Prof. Dr. R. Madsen

Department of Chemistry

Technical University of Denmark

$2800 \mathrm{Kgs}$. Lyngby (Denmark)

E-mail: rm@kemi.dtu.dk

Supporting information for this article is given via a link at the end of the document. shown to proceed through the amido complex of the corresponding manganese(III) salan species (Scheme 1). ${ }^{[6]}$ This discovery raises the question whether other manganese(III) complexes with tetradentate ligands would also be able to catalyze acceptorless dehydrogenations?

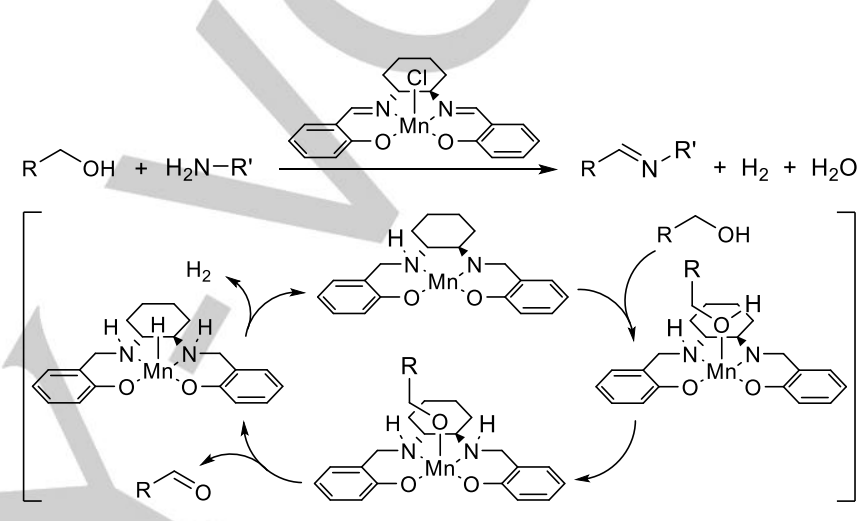

Scheme 1. Manganese(III) salen-catalyzed alcohol dehydrogenation and the mechanism.

Manganese(III) porphyrin complexes and related compounds are well known for catalyzing oxidation reactions in the presence of a stoichiometric oxidant including hydroxylation/halogenation of alkanes, epoxidation of alkenes and oxidation of alcohols. ${ }^{[7]}$ The transformations involve catalytic cycles with various manganese(III), (IV) and (V) species. ${ }^{[7]}$ However, no dehydrogenation of a functional group with the release of hydrogen gas has been reported before with these complexes.

Herein, we describe the development of different manganese(III) porphyrin complexes for catalyzing the dehydrogenative coupling of alcohols and amines to form imines, tertiary amines and quinoline. In addition, the mechanism has been investigated indicating another pathway for the dehydrogenation than with the manganese(III) salen complexes. The findings underline the unique reactivity of manganese(III) complexes with tetradentate ligands in hydrogen gas-releasing transformations.

\section{Results and Discussion}

Benzyl alcohol and cyclohexylamine were selected as the substrates for the exploratory experiments where several manganese(III) (tetraaza)porphyrin chloride complexes were investigated for the dehydrogenation (Figure 1). Notably, the common and commercially available tetraphenylporphyrin (TPP) complex A gave a good conversion into the imine $\mathbf{1}$ in the absence of any additional additives (Table 1, entry 1 ). The 
influence of the substituents on the tetradentate ligand was then examined and the yield decreased with the corresponding paracarboxylate complex B (entry 2). Electron-donating groups, on the other hand, had a beneficial effect on the imine formation and a quantitative yield was obtained with both the paramethoxy complex $\mathbf{C}$ and the para-(diethylamino) compound $\mathbf{D}$ (entries 3 and 4). Slightly lower yields were observed with tetramesityl- and octaethylporphyrin complexes $\mathbf{E}$ and $\mathbf{F}$, respectively, as well as with phthalocyanine complex $\mathbf{G}$ (entries $5-7$ ). Tert-butyl groups on the tetraazaporphyrin ring, on the other hand, had a beneficial effect on the transformation and a quantitative yield was obtained with complex $\mathbf{H}$ (entry 8). Except for complex B, all the investigated (tetraaza)porphyrin complexes were fully soluble under the reaction conditions.

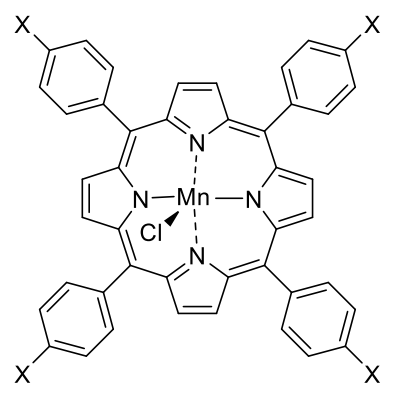

$$
\begin{aligned}
& \text { A: } X=\mathrm{H} \\
& \text { B: } X=\mathrm{COOH} \\
& \text { C: } X=\mathrm{OMe} \\
& \text { D: } X=\mathrm{NEt}_{2}
\end{aligned}
$$

C and D (entries 12 - 14). These results point towards complex $\mathbf{H}$ as the preferred catalyst for the dehydrogenation. Lowering the loading further to $1 \%$ gave a moderate yield of the imine and the same was observed when the reaction was performed in refluxing toluene (entries 15 and 16). Surprisingly, additives such as inorganic bases, phosphines and amines had essentially no impact on the transformation (see Table S1 in the supporting information). Hence, an optimized protocol has been developed where equimolar amounts of alcohol and amine are reacted with $2 \%$ of complex $\mathbf{H}$ in refluxing mesitylene to afford

\begin{tabular}{|c|c|c|c|c|}
\hline Entry & $x$ & Catalyst & $t[\mathrm{~h}]$ & Yield $[\%]^{[b]}$ \\
\hline 1 & 5 & A & 60 & 90 \\
\hline 2 & 5 & B & 60 & 55 \\
\hline 3 & 5 & C & 60 & 100 \\
\hline 4 & 5 & D & 60 & 100 \\
\hline 5 & 5 & E & 60 & 85 \\
\hline 6 & 5 & 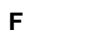 & 60 & 94 \\
\hline 7 & 5 & G & 60 & 83 \\
\hline 8 & 5 & H & 60 & 100 \\
\hline 9 & 3 & c & 48 & 88 \\
\hline 10 & 3 & D & 48 & 90 \\
\hline 11 & 3 & H & 48 & 100 \\
\hline 12 & 2 & C & 48 & 76 \\
\hline 13 & 2 & D & 48 & 83 \\
\hline 14 & 2 & H & 48 & 92 \\
\hline 15 & 1 & H & 48 & 68 \\
\hline $16^{[c]}$ & 5 & H & 48 & 50 \\
\hline
\end{tabular}
the corresponding imine.

Table 1. Optimizing manganese(III)-catalyzed alcohol dehydrogenation. ${ }^{[a]}$

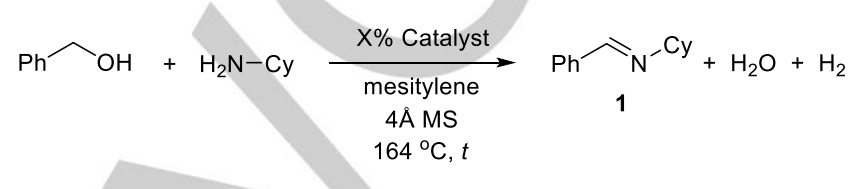

[a] Reaction conditions: $\mathrm{BnOH}(1 \mathrm{mmol}), \mathrm{CyNH}_{2}(1 \mathrm{mmol})$, catalyst $(0.0 \mathrm{X}$ $\mathrm{mmol})$, tetradecane $(0.5 \mathrm{mmol}$, internal standard $), 4 \AA \mathrm{AS}(150 \mathrm{mg})$, mesitylene $(4 \mathrm{~mL})$, reflux. [b] Determined by $\mathrm{GC}$. [c] In toluene at reflux.

This new method was then applied to several different alcohols and amines to explore the substrate scope of the transformation (Table 2). First, various alcohols were reacted with cyclohexylamine and the products were isolated by flash chromatography. This afforded a $85 \%$ yield of 1 with the parent benzyl alcohol while $p$-methyl- and $p$-(tert-butyl)benzyl alcohol gave 89 and $90 \%$ yield, respectively, of $\mathbf{2}$ and $\mathbf{3}$. The electronic 
properties of the para substituent had very little influence on the imination since both electron-donating (as methoxy and methylthio) and electron-withdrawing groups (as halides, trifluoromethyl and methoxycarbonyl) gave very similar yields of the products $4-\mathbf{1 0}$. Notably, no competing dehalogenation was observed with the $p$-chloro, $p$-bromo and $p$-iodo substrates. The only exception was $p$-nitrobenzyl alcohol, which furnished imine 11 in a moderate yield of $62 \%$ due to a concomitant reduction of the nitro group to give $N$-( $p$-aminobenzylidene)cyclohexylamine as a byproduct. Ortho substituted substrates gave a slightly lower yield than the corresponding para compounds as seen for o-methyl, o-chloro- and o-bromobenzyl alcohol which afforded imines 12 - 14 in $72-82 \%$ yield. 1-Naphthalenemethanol, on the contrary, gave a higher $88 \%$ yield of the resulting imine 15 .

Table 2. Imine formation from different alcohols and amines. ${ }^{[a]}$

$$
\begin{aligned}
& \widehat{\mathrm{R}} \widehat{\mathrm{OH}}+\mathrm{H}_{2} \mathrm{~N}-\mathrm{R}^{\prime} \stackrel{2 \% \mathrm{H}}{\text { mesitylene }} \mathrm{R} \curvearrowright \mathrm{N}^{-\mathrm{R}^{\prime}}+\mathrm{H}_{2}+\mathrm{H}_{2} \mathrm{O} \\
& 4 \AA \mathrm{MS} \\
& \triangle, 48 \mathrm{~h} \\
& \text { 1:85\% }
\end{aligned}
$$<smiles>COc1ccc(/C=N/C2CCCCC2)cc1</smiles><smiles>CSc1ccc(/C=N/Cl)cc1</smiles><smiles></smiles><smiles>[Mg][TeH4+]</smiles>
7: $86 \%$

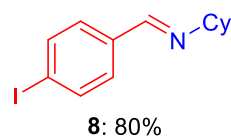
8: $80 \%$

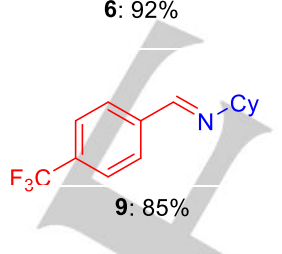<smiles>COC(=O)c1ccc(/C=N/C2CCCCC2)cc1</smiles>

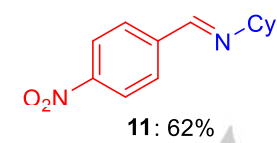<smiles>Cc1ccccc1/C=N/Cl</smiles>
12: $78 \%$<smiles>Cl/N=C/c1ccccc1Cl</smiles>
10: $80 \%$ 13: $72 \%$<smiles>C(=N/c1ccccc1)\c1ccccc1</smiles>

16: $92 \%$

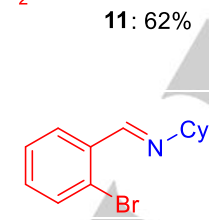
14: $82 \%$<smiles>Cc1ccc(Cl)c(/C=N/Br)c1</smiles>

17: $68 \%$

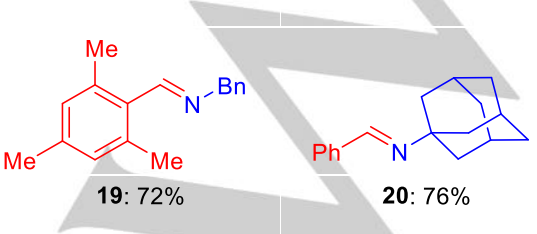

$$
\mathrm{Ph}_{\mathrm{N}^{-P h}}
$$

22: $80 \%$

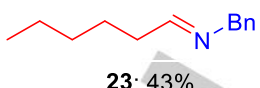

23: $43 \%$

[a] Reaction conditions: Alcohol (1 mmol), amine (1 mmol), H (0.02 mmol), $4 \AA$ MS (150 mg), mesitylene (4 mL), reflux, $48 \mathrm{~h}$ (isolated yields).

Changing the amine to benzylamine gave $92 \%$ yield of $\mathbf{1 6}$ with benzyl alcohol while slightly lower yields of imines $17-19$ were obtained with o-chloro, o-bromo- and 2,4,6-trimethylbenzyl alcohol. In the latter three cases, homocoupling of benzylamine to generate $\mathbf{1 6}$ was observed as a side reaction. The more hindered amines 1-adamantylamine and benzhydrylamine gave the corresponding imines 20 and 21 in 76 and $62 \%$ yield, respectively. The transformation could also be applied to arylamines where aniline afforded $80 \%$ yield of $\mathbf{2 2}$ in the reaction with benzyl alcohol. In addition, the imination could be performed with the aliphatic alcohol hexan-1-ol to give imine 23 in the reaction with benzylamine. Although full conversion of the alcohol was achieved, the isolated yield was only $43 \%$, which is due to the instability of $\mathbf{2 3}$ towards hydrolysis during the purification. When the crude reaction mixture was analyzed by NMR, the yield of $\mathbf{2 3}$ was determined to be $\mathbf{7 2} \%$ by comparison with an internal standard and after removing the catalyst.

The evolution of hydrogen gas was confirmed by performing the reaction in Table 1, entry 14 in a closed two-chamber system ${ }^{[8]}$ where the other compartment contained diphenylacetylene and $\mathrm{Pd} / \mathrm{C}$ in methanol. This experiment showed reduction of diphenylacetylene to (Z)-stilbene after full conversion into the imine and verifies the dehydrogenative pathway of the imine formation. When the experiment in Table 1, entry 14 was carried out with $\mathrm{PhCD}_{2} \mathrm{OH}$ instead of $\mathrm{PhCH}_{2} \mathrm{OH}$, the only product formed was $\mathrm{PhCD}=\mathrm{NCy}$ with no hydrogen incorporation into the benzylic position. This may indicate that the dehydrogenation takes place by a monohydride pathway and a metal-dihydride compound is not formed. Radical species do not appear to be part of the mechanism since addition of 2 equiv. of the scavengers 2,4-diphenyl-4-methylpent-1-ene and cyclohexa-1,4-diene had no influence on the conversion into the imine under the optimized conditions in Table 1, entry 14. The two scavengers were not converted during the transformations suggesting that the catalyst in unable to mediate the hydrogenation of olefins.

Table 3. Optimizing alkylation of secondary amine into tertiary amine. ${ }^{[a]}$

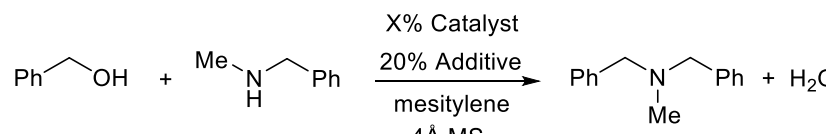

$$
\begin{aligned}
& 4 \AA ̊ \text { MS } \\
& 164{ }^{\circ} \mathrm{C}, 48 \mathrm{~h} \\
& 24
\end{aligned}
$$

\begin{tabular}{llll}
\hline Entry $\quad X \quad$ Catalyst $\quad$ Additive & $\begin{array}{l}\text { Conversion of } \\
\text { BnNHMe [\%] }\end{array}$ & Yield [\%] ${ }^{[b]}$ \\
\hline
\end{tabular}

$$
\text { 21: } 62 \%
$$

\begin{tabular}{llllll}
\hline 1 & 3 & A & - & 80 & 70 \\
2 & 3 & C & - & 82 & 68
\end{tabular}

(1)




\begin{tabular}{llllll}
3 & 3 & $\mathbf{H}$ & - & 85 & 65 \\
4 & 3 & $\mathbf{A}$ & $\mathrm{K}_{2} \mathrm{CO}_{3}$ & 100 & 88 \\
5 & 3 & $\mathbf{C}$ & $\mathrm{K}_{2} \mathrm{CO}_{3}$ & 100 & 81 \\
6 & 3 & $\mathbf{H}$ & $\mathrm{K}_{2} \mathrm{CO}_{3}$ & 100 & 80 \\
7 & 2 & $\mathbf{A}$ & $\mathrm{K}_{2} \mathrm{CO}_{3}$ & 100 & 81 \\
$8^{[c]}$ & 3 & $\mathbf{A}$ & $\mathrm{K}_{2} \mathrm{CO}_{3}$ & 100 & 93 \\
\hline
\end{tabular}

[a] Reaction conditions: $\mathrm{BnOH}(1 \mathrm{mmol}), \mathrm{BnNHMe}(1 \mathrm{mmol})$, catalyst $(0.0 \mathrm{X}$ $\mathrm{mmol}$ ), additive $(0.2 \mathrm{mmol})$, tetradecane $(0.5 \mathrm{mmol}$, internal standard), $4 \AA \mathrm{MS}$ (150 mg), mesitylene (4 mL), reflux, $48 \mathrm{~h}$. [b] Determined by GC. [c] With 1.2 $\mathrm{mmol}$ of $\mathrm{BnOH}$.

Dehydrogenative reactions between alcohols and amines can also be performed with secondary amines where the product is a tertiary amine. This transformation has been demonstrated with a variety of alcohols and amines when ruthenium, ${ }^{[9]}$ iridium, ${ }^{[10]}$ palladium ${ }^{[11]}$ and iron ${ }^{[12]}$ catalysts are employed. With manganese, however, only a special example exists with a manganese $(I)$ catalyst where activated aromatic compounds are aminomethylated with methanol and secondary amines. ${ }^{[13]}$ Thus, benzyl alcohol and $\mathrm{N}$-methyl benzylamine were selected as the starting substrates to investigate the alkylation where water is formed as the only byproduct. Interestingly, the reaction afforded the desired tertiary amine $\mathbf{2 4}$, but complete conversion of the starting amine was not observed with $3 \%$ of complexes A, $\mathbf{C}$ and $\mathbf{H}$ (Table 3, entries $1-3$ ). However, when $\mathrm{K}_{2} \mathrm{CO}_{3}$ was added as a basic additive, all three catalysts gave full conversion of the starting material (entries $4-6$ ). The highest yield was observed with complex $\mathbf{A}$, which seems to be the preferred catalyst in this case. Other additives were also investigated such as $\mathrm{KOtBu}, \mathrm{Cs}_{2} \mathrm{CO}_{3}, \mathrm{Ca}_{3} \mathrm{~N}_{2}, \mathrm{MgSO}_{4}, \mathrm{NaHCO}_{3}$ and pyridine, but no improvements were observed (results not shown). Lowering the loading of $\mathbf{A}$ to $2 \%$ decreased the yield (entry 7) while a slightly higher yield was obtained by increasing the amount of the alcohol to 1.2 equiv. (entry 8). These final conditions were selected for general use and applied to different alcohols and amines where the products again were isolated by flash chromatography (Table 4).

Table 4. Synthesis of tertiary amines from alcohols and secondary amines. ${ }^{[a]}$
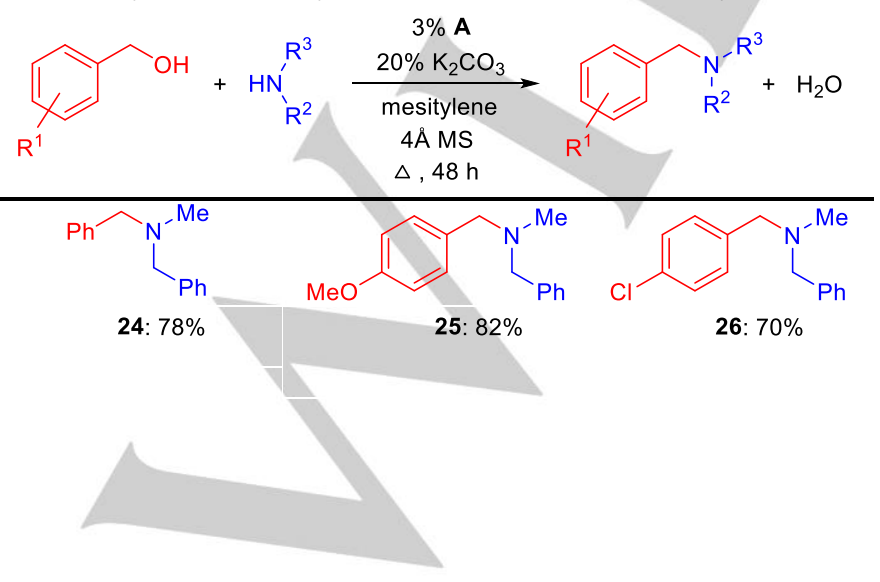

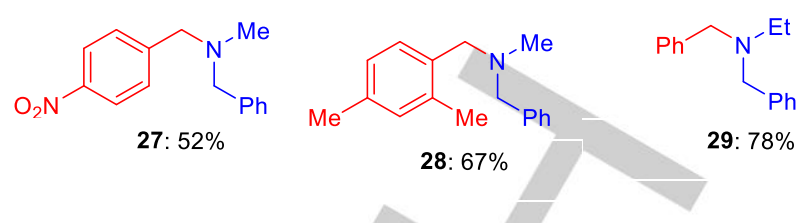<smiles>CCN(Cc1ccccc1)Cc1ccc(CN(Cc2ccc(C)cc2)Cc2ccc(OC)cc2CN(C)Cc2ccc(OC)cc2)cc1</smiles>
32: $80 \%$

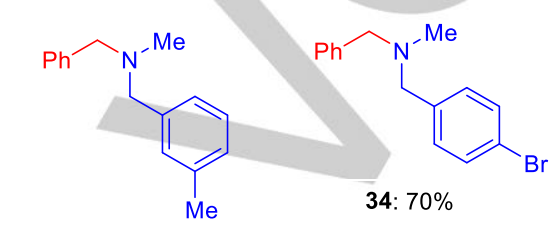

33: $73 \%$

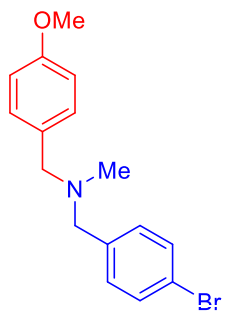

35: $86 \%$<smiles>COc1ccc(CN(Cc2ccccc2)Cc2ccc([N+](=O)[O-])cc2)cc1</smiles>

38: $65 \%$<smiles>COc1ccc(CN(C)Cc2cccc(Cl)c2)cc1</smiles>

37: $73 \%$<smiles>COc1ccc(CN(Cc2ccc(OC)cc2)Cc2ccc(C(C)(C)C)cc2)cc1</smiles><smiles>CCN(Cc1ccccc1)Cc1ccc(C(F)(F)F)cc1</smiles><smiles>CCN(CC)Cc1ccc(OC)cc1</smiles>

41: $58 \%$<smiles>Cc1ccc(C(F)(F)F)cc1</smiles><smiles>c1ccc(CN(Cc2ccccc2)Cc2ccccc2)cc1</smiles><smiles>C=CCN(Cc1ccccc1)Cc1ccccc1</smiles><smiles>c1ccc(CN2CCCCC2)cc1</smiles>

43: $62 \%$<smiles>c1ccc(CN2CCOCC2)cc1</smiles><smiles>CCN(Cc1ccccc1)c1ccccc1</smiles>

46: $47 \%$
44: $70 \%$<smiles>c1ccc(CN2CCCc3ccccc32)cc1</smiles>

47: $35 \%$ 
[a] Reaction conditions: Alcohol (1.2 mmol), amine (1 mmol), A $(0.03 \mathrm{mmol})$, $\mathrm{K}_{2} \mathrm{CO}_{3}(0.2 \mathrm{mmol}), 4 \AA ̊ \mathrm{MS}(150 \mathrm{mg})$, mesitylene $(4 \mathrm{~mL})$, reflux, $48 \mathrm{~h}$ (isolated yields).

The transformation afforded a $78 \%$ isolated yield of the parent compound $\mathbf{2 4}$ while $p$-methoxy- and p-chlorobenzyl alcohol gave 82 and $70 \%$ yield, respectively, of $\mathbf{2 5}$ and $\mathbf{2 6}$ in the reaction with $\mathrm{N}$-methyl benzylamine. In the same reaction, $p$ nitrobenzyl alcohol provided the tertiary amine $\mathbf{2 7}$ in a moderate yield of $52 \%$ due to several byproducts whereas 2,4dimethylbenzyl alcohol furnished the corresponding amine $\mathbf{2 8}$ in $67 \%$ yield. $N$-Ethyl benzylamine gave the same yields as the $N$ methyl analogue in the reaction with benzyl and $p$ methoxybenzyl alcohol to afford 29 and 30 . N-Methyl $p$ methylbenzylamine produced $80 \%$ yield of both $\mathbf{3 1}$ and $\mathbf{3 2}$ in the reaction with the two alcohols while the alkylation of $\mathrm{N}$-methyl $\mathrm{m}$ methylbenzylamine with benzyl alcohol resulted in 33 in $73 \%$ yield. Benzyl and p-methoxybenzyl alcohol were also reacted with $\quad N$-methyl $p$-bromobenzylamine, $N$-methyl $m$ chlorobenzylamine, $N$-(p-methylbenzyl) $p$-methoxybenzylamine and $N$-ethyl $p$-(trifluoromethyl)benzylamine where the products $34-41$ were isolated in $58-86 \%$ yield. Tribenzylamine (42) was obtained in $75 \%$ yield upon reaction between dibenzylamine and benzyl alcohol while $N$-allyl benzylamine was $N$-benzylated to give $\mathbf{4 3}$ in $62 \%$ yield without any accompanying reduction of the olefin. In the same way, piperidine and morpholine were $\mathrm{N}$ benzylated to afford $\mathbf{4 4}$ and $\mathbf{4 5}$ in 70 and $66 \%$ yield whereas the arylamines $N$-ethylaniline and tetrahydroquinoline underwent the benzylation to provide 46 and 47 in only 47 and $35 \%$ yield, respectively. In the latter case, tetrahydroquinoline was converted into quinoline as a side reaction while $\mathrm{N}$-ethylaniline did not undergo complete conversion in the transformation. Thus, the nucleophilicity of the amine influences the alkylation resulting in lower yields with less nucleophilic substrates. The aliphatic alcohol hexan-1-ol was also investigated, but a very poor conversion was observed in the reaction with $\mathrm{N}$-methy benzylamine (result not shown).

Besides the dehydrogenation of tetrahydroquinoline, the quinoline framework can also be prepared by a dehydrogenative coupling between $o$-aminobenzyl alcohols and secondary alcohols. The condensation between the corresponding carbonyl compounds is known as the Friedländer quinoline synthesis, but often suffers from a moderate yield due to the limited stability of o-aminobenzaldehydes and undesired aldol condensations. ${ }^{[14]}$ These side reactions occur to a lower degree in the dehydrogenative quinoline synthesis from alcohols, which has previously been catalyzed by different ruthenium and iridium complexes $\left(0.025-0.5 \% \text { loading at } 110^{\circ} \mathrm{C}\right)^{[15]}$ as well as various copper, nickel, cobalt and manganese(I) compounds (2 $-10 \%$ loading at $\left.90-150{ }^{\circ} \mathrm{C}\right) .{ }^{[16]}$ All the transformations are carried out in the absence of a hydrogen acceptor, but $0.5-3$ equiv. of a base is required such as $\mathrm{KOH}$ or $\mathrm{KO} t \mathrm{Bu} .{ }^{[15,16]}$

To develop a new manganese(III)-catalyzed quinoline synthesis, several exploratory experiments were first performed with equimolar amounts of o-aminobenzyl alcohol and 1phenylethanol in the presence of complex $\mathbf{A}$ (Table 5). It was quickly realized that $\mathrm{K}_{2} \mathrm{CO}_{3}$ was not a sufficiently strong base in this case since it only gave 2-phenylquinoline (48) in $9 \%$ yield (entry 1) while $\mathrm{KOH}, \mathrm{NaOH}$ and $\mathrm{KO}$ tBu afforded $21-32 \%$ yield (entries $2-4$ ). Combining $\mathrm{KOH}$ and $\mathrm{KO}$ tBu gave an improved outcome (entry 5 ) and especially when the reaction time was extended (entry 6). A further increase in the yield was obtained upon adding a small amount of pyridine as an additional base (entry 7) and with 1.5 equiv. of 1 -phenylethanol the target quinoline was produced in $76 \%$ yield (entry 8 ). No improvement was observed by further increasing the amount of 1 phenylethanol (entry 9) while the yield decreased with lower amounts of complex A (entry 10) or with only one of the inorganic bases (entries 11 and 12). Thus, an optimized protocol has been established where quinolines are prepared by reacting o-aminobenzyl alcohols with 1.5 equiv. of secondary alcohols in the presence of $5 \%$ of complex $\mathbf{A}$ and a mixture of $\mathrm{KOH}, \mathrm{KO} \mathrm{tBu}$ and pyridine.

Table 5. Optimizing dehydrogenative quinoline synthesis. ${ }^{[a]}$

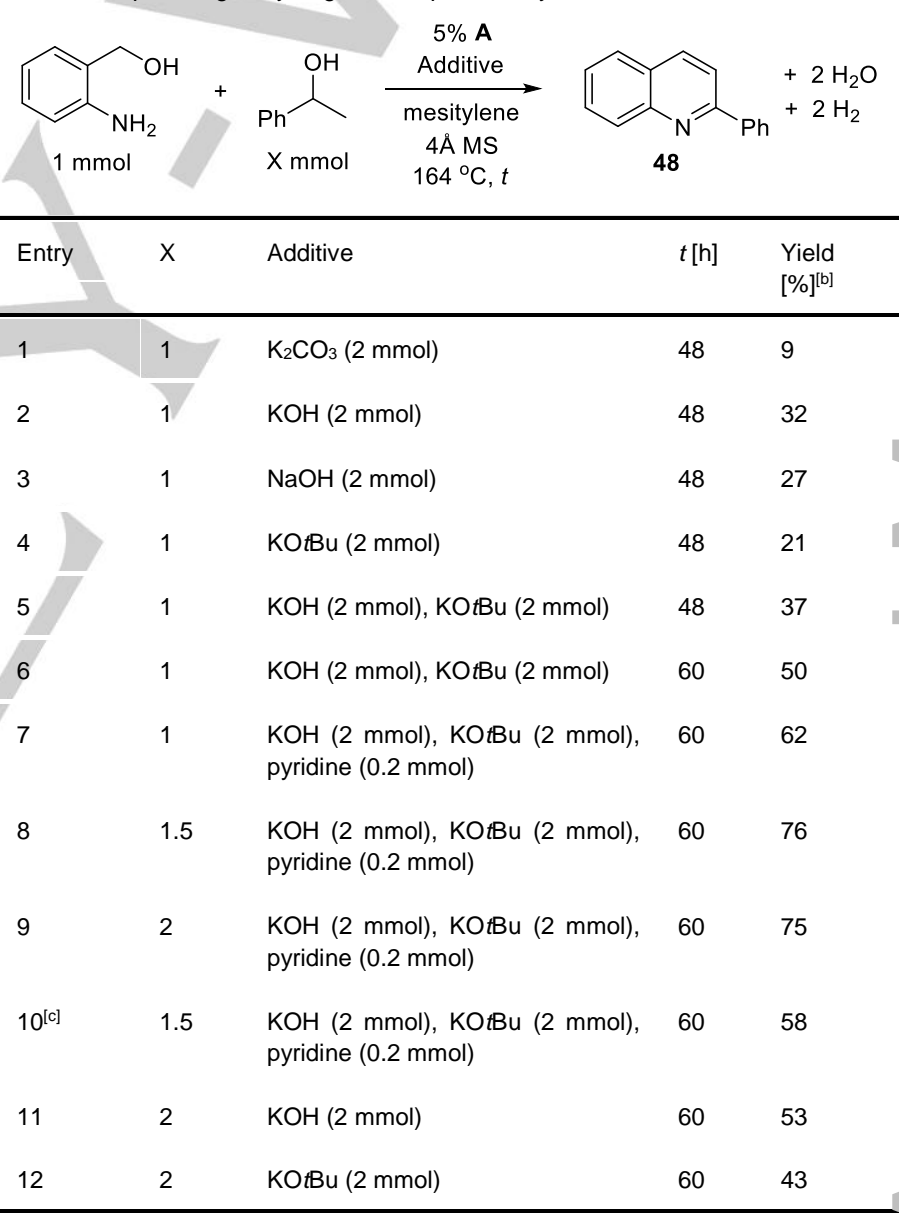

[a] Reaction conditions: o-Aminobenzyl alcohol (1 mmol), 1-phenylethanol (X $\mathrm{mmol})$, A (0.05 mmol), additive, tetradecane (0.5 mmol, internal standard), $4 \AA$ MS (150 mg), mesitylene (4 mL), reflux. [b] Determined by GC. [c] With $3 \%$ of $\mathbf{A}$.

The substrate scope of this new procedure was then investigated with a variety of alcohols and the products were isolated by column chromatography (Table 6). In this way, 2phenylquinoline (48) was obtained in $70 \%$ yield while the 
corresponding 2-( $p$-tolyl) compound $\mathbf{4 9}$ was formed in $90 \%$ yield. 1 -( $p$-Methoxyphenyl)- and 1-( $p$-methylthiophenyl)ethanol reacted with o-aminobenzyl alcohol to give quinolines $\mathbf{5 0}$ and $\mathbf{5 1}$, respectively, in 93 and $82 \%$ yield. In the same reaction, $1-(p-$ fluorophenyl)-, 1-(o-chlorophenyl)- and 1-( $p$ bromophenyl)ethanol gave the related quinolines $52-54$ in $78-$ $87 \%$ yield while a slightly lower yield was obtained of $2-(p-$ iodophenyl)quinoline (55) due to partial dehalogenation. Similar reactions were carried out with 2-amino-4-chlorobenzyl alcohol which reacted with 1-phenyl-, 1-(p-tolyl)-, 1-(p-methoxyphenyl)and 1 -( $p$-fluorophenyl)ethanol to give the corresponding 2-aryl-7chloroquinolines 56 - 59 in $62-82 \%$ yield. Again, a more modest result was obtained with 1 -( $p$-iodophenyl)ethanol giving 7 -chloro-2-( $p$-iodophenyl)quinoline (60) in $53 \%$ yield due to some dehalogenation. The transformation could also be performed with cyclohexanol and cycloheptanol to afford tricyclic compounds 61 and 62, respectively, in 48 and $56 \%$ yield. $p$ Nitro- and p-cyano-substituted 1-phenylethanol, on the other hand, failed to produce the desired quinolines, but instead a complex mixture was obtained (results not shown).

Table 6. Synthesis of quinolines from o-aminobenzyl alcohols and secondary

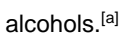

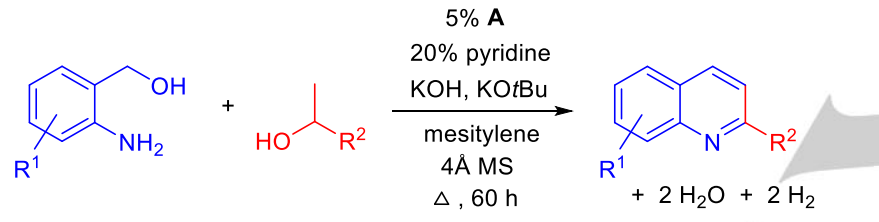
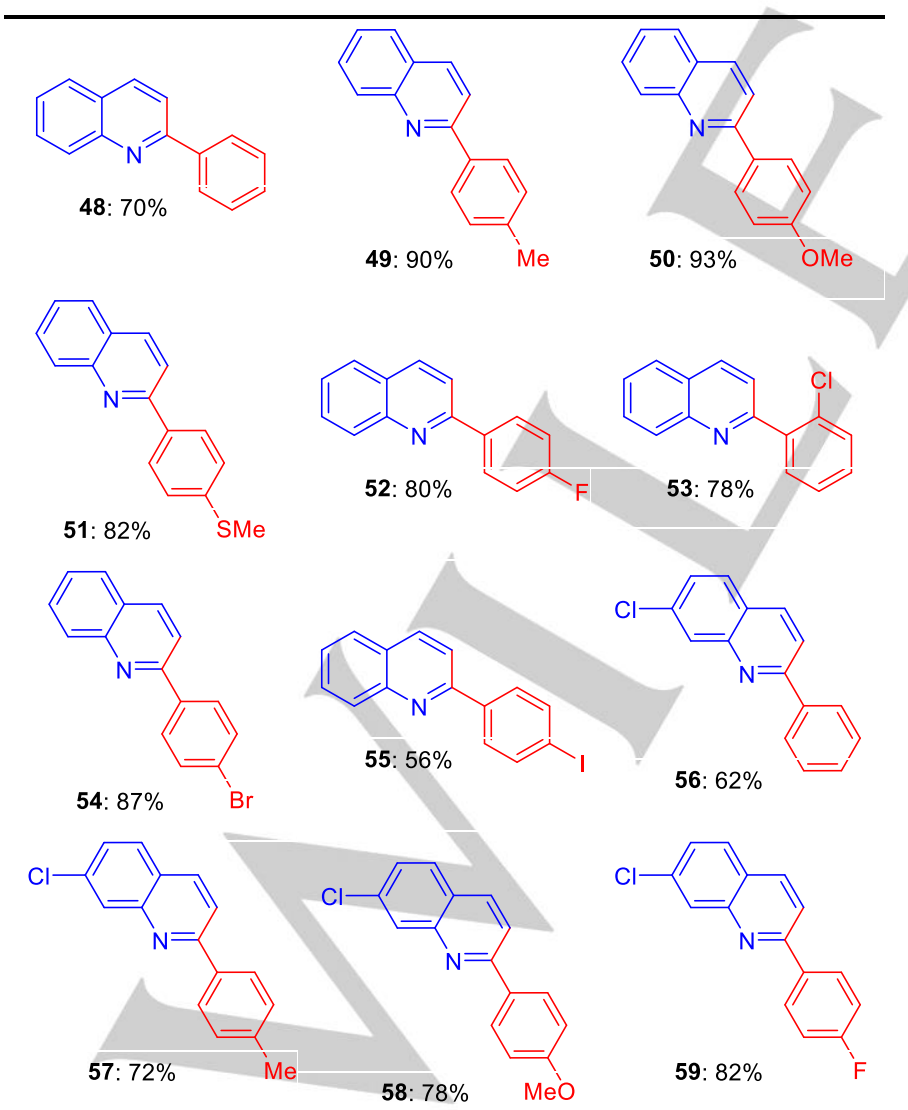
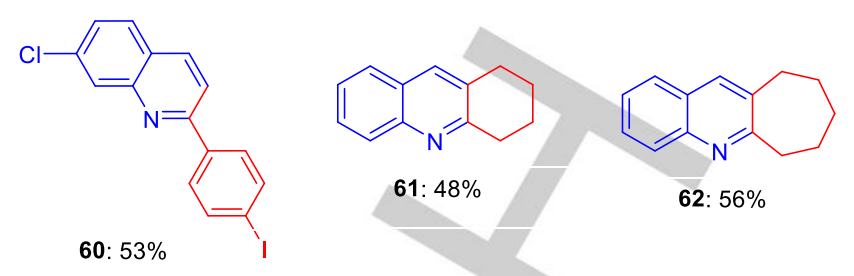

[a] Reaction conditions: o-Aminobenzyl alcohol $(1 \mathrm{mmol})$, secondary alcohol (1.5 mmol), A (0.05 mmol), pyridine $(0.2 \mathrm{mmol}), \mathrm{KOH}(2 \mathrm{mmol}), \mathrm{KOtBu}(2$ $\mathrm{mmol}), 4 \AA \mathrm{MS}$ (150 mg), mesitylene (4 mL), reflux, $60 \mathrm{~h}$ (isolated yields).

To gain more information about the mechanism several experiments were performed to investigate the fate of the porphyrin complex during the reaction. LCMS analysis of the mixture after the imination in Table 1 , entry 1 showed only porphyrin complex $\mathbf{A}$ and no compounds with a reduced ligand could be detected, i.e. the corresponding chlorin or bacteriochlorin complexes. Complex $\mathbf{A}$ could be recovered in $70 \%$ yield and used again in the same reaction although the yield then decreased to $58 \%$. When the experiment was carried out with $\mathrm{PhCD}_{2} \mathrm{OH}$ and $\mathrm{CyNH}_{2}, 1-4$ deuterium atoms were incorporated into complex $\mathbf{A}$. This must be in the $\beta$-pyrrolic positions, which was confirmed by isolating the complex, subjecting it to demetallation with acid and analyzing the ligand by NMR spectroscopy. On the other hand, when the imination with $\mathrm{PhCD}_{2} \mathrm{OH}$ and $\mathrm{CyNH}_{2}$ was carried out with complex $\mathbf{F}$, no deuterium incorporation occurred in the porphyrin ring. Thus, a hydrogen - deuterium scrambling is possible in the $\beta$-positions of the porphyrin by using $\mathrm{PhCD}_{2} \mathrm{OH}$ as the substrate, but no incorporation occurs in the meso positions.

The main structural feature of the porphyrin ring is the aromatic $18 \pi$-electron conjugated network. Two pyrrole double bonds in the $\beta$-positions are not part of this system and these two bonds are susceptible to hydrogenation to afford the chlorin and the bacteriochlorin structure. ${ }^{[17]}$ On the contrary, these hydroporphyrins are rather easily oxidized back to the parent porphyrin macrocycle. It seems inconceivable that $\mathrm{PhCD}_{2} \mathrm{OH}$ coordinates to manganese and transfers deuterium to the $\beta$ positions in a similar way as the reduction of the Schiff bases in the salen complexes. ${ }^{[6]}$ It also appears highly unlikely that the 18 $\pi$-electron pathway is disrupted during the process since this usually requires very strong nucleophiles such as organolithium reagents. ${ }^{[18]}$ Therefore, the most reasonable explanation for the deuterium introduction is a partial reduction of the porphyrin ring by an external reducing agent in the mixture. To test this scenario complex $\mathbf{A}$ was treated with $\mathrm{NaBH}_{4}$ and $\mathrm{NaBD}_{4}$ in two separate experiments in DMSO at $120^{\circ} \mathrm{C}$. In both cases, the manganese(III) chlorin complex could be detected by LCMS analysis of the mixture. However, after workup only the porphyrin complex was isolated which is presumably due to aerobic oxidation of the chlorin compound. In the experiment with $\mathrm{NaBD}_{4}$ some incorporation of deuterium occurred into the porphyrin framework and again it was confirmed by NMR to be in the $\beta$-pyrrolic positions. This experiment shows that a 
reducing agent is able to react with the porphyrin ring and result in deuterium incorporation.

Another experiment was designed by using a closed system with two connected reaction vessels and a balloon. The imination with $\mathrm{PhCH}_{2} \mathrm{OH}, \mathrm{CyNH}_{2}$ and complex $\mathbf{A}$ (Table 1, entry 1) was carried out in the first vessel while in the second vessel (with the balloon attached) $\mathrm{DCl}$ in $\mathrm{D}_{2} \mathrm{O}$ was added to zinc metal. ${ }^{[19]}$ This liberated $D_{2}$ in the second vessel, which was transferred to the first vessel. Subsequent analysis of complex $\mathbf{A}$ after the imination reaction revealed deuterium incorporation into the complex while no isotope insertion occurred in the alcohol or the imine. This again indicates that reduction of the porphyrin takes place by a reducing agent in the mixture (such as a metal hydride) and not directly by the alcohol.

Thus, manganese(III) porphyrin complexes with axial hydride and alkoxide ligands are most likely formed as intermediates in the reaction. To the best of our knowledge such complexes have not previously been structurally characterized. ${ }^{[20,21]}$ To gain some experimental evidence for the formation of these complexes, an experiment was carried out where complex $\mathbf{A}(1 \mathrm{mmol})$ was mixed with $\mathrm{BnOH}(50 \mathrm{mmol})$ and $\mathrm{NaH}(10 \mathrm{mmol})$ in mesitylene. After stirring for $30 \mathrm{~min}$ at room temperature LCMS analysis of the mixture showed complete conversion of complex $\mathbf{A}$ into the benzyloxy complex (TPP)Mn"'(OBn). The mixture was then slowly heated to $180{ }^{\circ} \mathrm{C}$ with a distillation head attached which resulted in $3 \mathrm{mmol}$ of a $6: 1$ mixture of benzyl alcohol and benzaldehyde distilling off from the reaction. GC analysis of the residue showed benzyl alcohol and small amounts of benzaldehyde. This test illustrates that a manganese(III) alkoxide complex can undergo degradation with the formation of the aldehyde (and most likely the corresponding manganese(III) hydride complex).

Based on these observations we believe the most probable mechanism involves initial formation of the alkoxide complex 63 (Scheme 2). No coordination site is available in this compound for a classical $\beta$-hydride elimination. However, a related rhodium(III) porphyrin complex was shown to react with isopropanol to produce acetone and the rhodium(III) hydride species $^{[22]}$ although the exact mechanism for this reaction is not known. ${ }^{[23]}$ In addition, (TPP) $\mathrm{Rh}^{\text {"II }} \mathrm{Cl}$ was shown to mediate the photocatalytic conversion of secondary alcohols into ketones and hydrogen gas. ${ }^{[24]}$ Therefore, we contemplate that alkoxide complex 63 can be converted into the aldehyde and hydride complex 64 in refluxing mesitylene. ${ }^{[25]}$ Subsequent reaction with the alcohol regenerates complex 63 and forms hydrogen gas. This is a different mechanistic pathway than elucidated for the manganese(III) salen-catalyzed alcohol dehydrogenation in refluxing toluene (Scheme 1). ${ }^{[6]}$ The higher temperature needed for the porphyrin-catalyzed protocol is most likely due to the conversion of the alkoxide complex $\mathbf{6 3}$ into the hydride species 64.

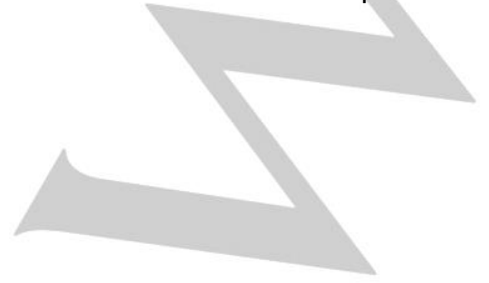

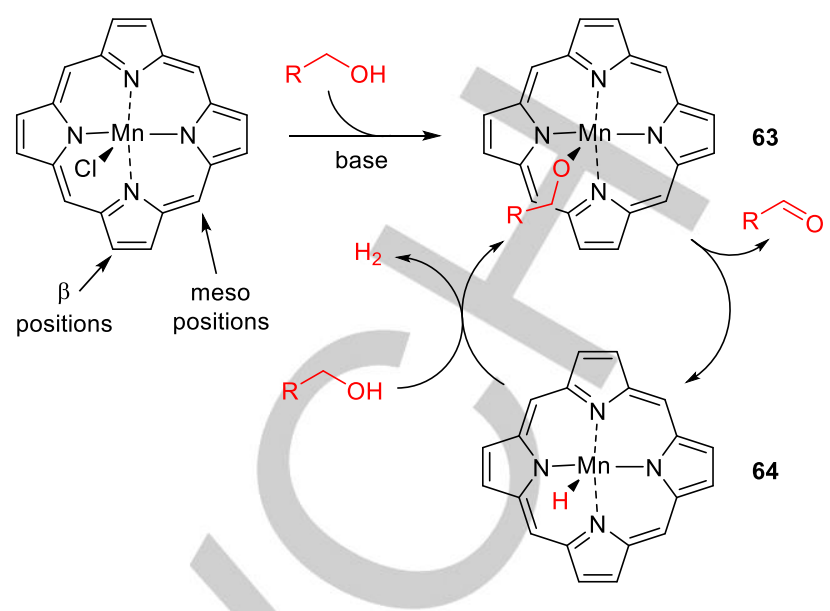

Scheme 2. Proposed mechanism for acceptorless alcohol dehydrogenation.

\section{Conclusions}

In summary, manganese(III) porphyrin complexes have been shown to catalyze the dehydrogenation of alcohols with the release of hydrogen gas. The transformation has been applied to the direct synthesis of imines, tertiary amines and quinolines from alcohols and amines. The reactions are believed to proceed through a porphyrin manganese(III) alkoxide complex as the intermediate. Experimental studies have indicated that this complex can degrade with the formation of the aldehyde and most likely the corresponding hydride complex. Subsequent reaction between the latter and the alcohol forms hydrogen gas and regenerates the alkoxide complex. This constitutes the second example of a manganese(III) catalyst for the acceptorless dehydrogenation of alcohols, but contrary to the first example with a salen complex the porphyrin complexes react by a different mechanism.

\section{Experimental Section}

General procedure for imine synthesis: An oven-dried tube $(20 \mathrm{~mL})$ was charged with complex $\mathbf{H}(12 \mathrm{mg}, 0.02 \mathrm{mmol})$ and pre-activated $4 \AA$ molecular sieves $(150 \mathrm{mg})$. The tube was placed in a Radley carousel on a hotplate, subjected to vacuum and then filled with $\mathrm{N}_{2}$ (repeated 3 times). Freshly degassed mesitylene $(4 \mathrm{~mL})$ was injected into the mixture followed by heating to $164{ }^{\circ} \mathrm{C}$ under a $\mathrm{N}_{2}$ atmosphere. Then, the alcohol $(1 \mathrm{mmol})$, the amine $(1 \mathrm{mmol})$ and tetradecane $(0.5 \mathrm{mmol}$, internal standard) were added to the blue solution and the reaction was refluxed for $48 \mathrm{~h}$. The mixture was purified directly by silica gel column chromatography (hexane/ $\mathrm{Et}_{3} \mathrm{~N}, 98: 2$ ) to obtain the desired product.

General procedure for tertiary amine synthesis: Complex A $(20 \mathrm{mg}$, $0.03 \mathrm{mmol}), \mathrm{K}_{2} \mathrm{CO}_{3}(20 \mathrm{mg}, 0.2 \mathrm{mmol})$ and pre-activated $4 \AA$ molecular sieves $(150 \mathrm{mg})$ were placed in an oven-dried tube $(20 \mathrm{~mL})$. The tube was placed in a Radley carousel on a hotplate, subjected to vacuum and then filled with $\mathrm{N}_{2}$ (repeated 3 times). Freshly degassed mesitylene $(4 \mathrm{~mL}$ ) was injected into the mixture followed by heating to $164{ }^{\circ} \mathrm{C}$ under a $\mathrm{N}_{2}$ atmosphere. Then, the alcohol $(1.2 \mathrm{mmol})$, the amine $(1 \mathrm{mmol})$ and tetradecane $(0.5 \mathrm{mmol}$, internal standard) were added to the green solution and the reaction was refluxed for $48 \mathrm{~h}$. The mixture was purified 
directly by silica gel column chromatography (hexane/ $E t_{3} N, 98: 2$ ) to obtain the desired product.

General procedure for quinoline synthesis: Complex A (35 mg, 0.05 $\mathrm{mmol}), 2$-aminobenzyl alcohol (1 mmol), $\mathrm{KOH}(2 \mathrm{mmol}), \mathrm{KOtBu}(2 \mathrm{mmol})$ and pre-activated $4 \AA \AA$ molecular sieves $(150 \mathrm{mg})$ were placed in an ovendried tube $(20 \mathrm{~mL})$. The tube was placed in a Radley carousel on a hotplate, subjected to vacuum and then filled with $\mathrm{N}_{2}$ (repeated 3 times). Freshly degassed mesitylene $(4 \mathrm{~mL})$ was injected into the mixture followed by heating to $164{ }^{\circ} \mathrm{C}$ under a $\mathrm{N}_{2}$ atmosphere. Then, the secondary alcohol $(1.5 \mathrm{mmol})$, pyridine $(0.2 \mathrm{mmol})$ and tetradecane $(0.5$ mmol, internal standard) were added to the green solution and the reaction was refluxed for $60 \mathrm{~h}$. The mixture was concentrated and the residue purified by silica gel column chromatography $\left(\mathrm{CH}_{2} \mathrm{Cl}_{2} /\right.$ hexane, 1:1) to obtain the desired product.

\section{Acknowledgements}

We thank the Torkil Holm Foundation for financial support.

Keywords: alcohols $\cdot$ dehydrogenation $\cdot$ homogeneous catalysis $\cdot$ manganese $\cdot$ synthetic methods

[1] a) A. Corma, J. Navas, M. J. Sabater, Chem. Rev. 2018, 118, 1410 1459; b) C. Gunanathan, D. Milstein, Science 2013, 341, 1229712; c) S Bähn, S. Imm, L. Neubert, M. Zhang, H. Neumann, M. Beller, ChemCatChem 2011, 3, 1853-1864; d) Y. Obora, Y. Ishii, Synlett 2011 30-51; e) G. E. Dobereiner, R. H. Crabtree, Chem. Rev. 2010, 110, $681-703$.

[2] a) G. A. Filonenko, R. van Putten, E. J. M. Hensen, E. A. Pidko, Chem. Soc. Rev. 2018, 47, 1459-1483; b) F. Kallmeier, R. Kempe, Angew. Chem. Int. Ed. 2018, 57, 46-60; Angew. Chem. 2018, 130, 48-63; c) B. Maji, M. K. Barman, Synthesis 2017, 49, 3377-3393; d) M. Garbe, K. Junge, M. Beller, Eur. J. Org. Chem. 2017, 4344-4362; e) E. Balaraman, A. Nandakumar, G. Jaiswal, M. K. Sahoo, Catal. Sci. Technol. 2017, 7, 3177-3195.

[3] A. Mukherjee, A. Nerush, G. Leitus, L. J. W. Shimon, Y. Ben David, N. A. E. Jalapa, D. Milstein, J. Am. Chem. Soc. 2016, 138, 4298-4301.

[4] For recent examples, see: a) U. K. Das, S. Chakraborty, Y. DiskinPosner, D. Milstein, Angew. Chem. Int. Ed. 2018, 57, 13444-13448; Angew. Chem. 2018, 130, 13632-13636; b) T. Liu, L. Wang, K. Wu, Z. Yu, ACS Catal. 2018, 8, 7201-7207; c) G. Zhang, T. Irrgang, T. Dietel, F. Kallmeier, R. Kempe, Angew. Chem. Int. Ed. 2018, 57, 9131-9135 Angew. Chem. 2018, 130, 9269-9273; d) M. K. Barman, S. Waiba, B. Maji, Angew. Chem. Int. Ed. 2018, 57, 9126-9130; Angew. Chem. 2018 130, 9264-9268.

[5] For recent examples, see: a) A. Kaithal, M. Hölscher, W. Leitner, Angew. Chem. Int. Ed. 2018, 57, 13449-13453; Angew. Chem. 2018 130, 13637-13641; b) Y.-Q. Zou, S. Chakraborty, A. Nerush, D. Oren, Y. Diskin-Posner, Y. Ben-David, D. Milstein, ACS Catal. 2018, 8, 80148019 ; c) M. Glatz, B. Stöger, D. Himmelbauer, L. F. Veiros, K. Kirchner, ACS Catal. 2018, 8, 4009-4016; d) D. Wei, A. Bruneau-Voisine, T. Chauvin, V. Dorcet, T. Roisnel, D. A. Valyaev, N. Lugan, J.-B. Sortais, Adv. Synth. Catal. 2018, 360, 676-681.

[6] S. V. Samuelsen, C. Santilli, M. S. G. Ahlquist, R. Madsen, Chem. Sci. 2019, 10, 1150-1157.

[7] a) M. J. F. Calvete, M. Piñeiro, L. D. Dias, M. M. Pereira, ChemCatChem 2018, 10, 3615-3635; b) W. Liu, J. T. Groves, Acc. Chem. Res. 2015, 48, 1727-1735; c) M. Costas, Coord. Chem. Rev. 2011, 255, 2912-2932; d) C.-M. Che, V. K.-Y. Lo, C.-Y. Zhou, J.-S. Huang, Chem. Soc. Rev. 2011, 40, 1950-1975; e) H. Lu, X. P. Zhang, Chem. Soc. Rev. 2011, 40, 1899-1909.
[8] a) K. Azizi, R. Madsen, ChemCatChem 2018, 10, 3703-3708; b) P Hermange, A. T. Lindhardt, R. H. Taaning, K. Bjerglund, D. Lupp, T. Skrydstrup, J. Am. Chem. Soc. 2011, 133, 6061-6071.

[9] a) R. Figliolia, S. Baldino, H. G. Nedden, A. Zanotti-Gerosa, W. Baratta Chem. Eur. J. 2017, 23, 14416-14419; b) A. J. A. Watson, A. C. Maxwell, J. M. J. Williams, J. Org. Chem. 2011, 76, 2328-2331; c) A. Tillack, D. Hollmann, K. Mevius, D. Michalik, S. Bähn, M. Beller, Eur. J. Org. Chem. 2008, 4745-4750; d) S. Ganguly, D. M. Roundhill, Polyhedron 1990, 9, 2517-2526.

[10] a) Q. Zou, C. Wang, J. Smith, D. Xue, J. Xiao, Chem. Eur. J. 2015, 21 9656-9661; b) L. L. R. Lorentz-Petersen, L. U. Nordstrøm, R. Madsen, Eur. J. Org. Chem. 2012, 6752-6759; c) N. Andrushko, V. Andrushko, P. Roose, K. Moonen, A. Börner, ChemCatChem 2010, 2, 640-643; d) K.-i. Fujita, Y. Enoki, R. Yamaguchi, Tetrahedron 2008, 64, 1943-1954.

[11] a) R. Mamidala, V. Mukundam, K. Dhanunjayarao, K. Venkatasubbaiah, Tetrahedron 2017, 73, 2225-2233; b) T. T. Dang, B. Ramalingam, S. P. Shan, A. M. Seayad, ACS Catal. 2013, 3, 2536-2540.

[12] a) T. J. Brown, M. Cumbes, L. J. Diorazio, G. J. Clarkson, M. Wills, J. Org. Chem. 2017, 82, 10489-10503; b) T. Yan, B. L. Feringa, K. Barta, ACS Catal. 2016, 6, 381-388.

[13] M. Mastalir, E. Pittenauer, G. Allmaier, K. Kirchner, J. Am. Chem. Soc. 2017, 139, 8812-8815.

[14] J. Marco-Contelles, E. Pérez-Mayoral, A. Samadi, M. do Carmo Carreiras, E. Soriano, Chem. Rev. 2009, 109, 2652-2671.

[15] a) B. Pan, B. Liu, E. Yue, Q. Liu, X. Yang, Z. Wang, W.-H. Sun, ACS Catal. 2016, 6, 1247-1253; b) S. Ruch, T. Irrgang, R. Kempe, Chem. Eur. J. 2014, 20, 13279-13285; c) D. Srimani, Y. Ben-David, D. Milstein, Chem. Commun. 2013, 49, 6632-6634.

[16] a) K. Das, A. Mondal, D. Srimani, Chem. Commun. 2018, 54, $10582-$ 10585; b) S. Shee, K. Ganguli, K. Jana, S. Kundu, Chem. Commun. 2018, 54, 6883-6886; c) S. Das, D. Maiti, S. De Sarkar, J. Org. Chem. 2018, 83, 2309-2316; d) D.-W. Tan, H.-X. Li, D.-L. Zhu, H.-Y. Li, D. J. Young, J.-L. Yao, J.-P. Lang, Org. Lett. 2018, 20, 608-611; e) S. Parua, R. Sikari, S. Sinha, S. Das, G. Chakraborty, N. D. Paul, Org. Biomol. Chem. 2018, 16, 274-284; f) S. P. Midya, V. G. Landge, M. K. Sahoo, J. Rana, E. Balaraman, Chem. Commun. 2018, 54, 90-93; g) M. Mastalir, M. Glatz, E. Pittenauer, G. Allmaier, K. Kirchner, J. Am. Chem. Soc. 2016, 138, 15543-15546.

[17] M. Taniguchi, J. S. Lindsey, Chem. Rev. 2017, 117, 344-535.

[18] a) S. Hiroto, Y. Miyake, H. Shinokubo, Chem. Rev. 2017, 117, 2910 3043; b) M. O. Senge, Acc. Chem. Res. 2005, 38, 733-743.

[19] A. Modvig, T. L. Andersen, R. H. Taaning, A. T. Lindhardt, T. Skrydstrup, J. Org. Chem. 2014, 79, 5861-5868.

[20] For X-ray structures of two alkoxide complexes of iron(III) porphyrins, see: a) L. Cheng, N. Xu, D. R. Powell, G. B. Richter-Addo, Acta Cryst 2010, E66, m1448; b) K. Hatano, T. Uno, Bull. Chem. Soc. Jpn. 1990, 63, 1825-1827.

[21] An iron(III) porphyrin complex has been shown to catalyze the transfer hydrogenation of 2-methoxyacetophenone in isopropanol, but the mechanism has not been investigated, see: S. Enthaler, B. Spilker, G. Erre, K. Junge, M. K. Tse, M. Beller, Tetrahedron 2008, 64, 3867-3876.

[22] L. Liu, M. Yu, B. B. Wayland, X. Fu, Chem. Commun. 2010, 46, 6353 6355.

[23] For a discussion of possible mechanistic paths for this transformation, see: J. P. Collman, R. Boulatov, Inorg. Chem. 2001, 40, 560-563.

[24] X. Li, S. Shinoda, Y. Saito, J. Mol. Catal. 1989, 49, 113-119.

[25] A dissociative $\beta$-hydride abstraction mechanism has been proposed to explain formal $\beta$-hydride eliminations in alkoxide complexes where open cis coordination sites or detachable ligands are not available, see: a) N. A. Smythe, K. A. Grice, B. S. Williams, K. I. Goldberg Organometallics 2009, 28, 277-288; b) C. M. Fafard, O. V. Ozerov, Inorg. Chim. Acta 2007, 360, 286-292; c) O. Blum, D. Milstein, J. Organomet. Chem. 2000, 593-594, 479-484. 
Entry for the Table of Contents (Please choose one layout)

Layout 1:

\section{FULL PAPER}

Text for Table of Contents

Layout 2:

\section{FULL PAPER}

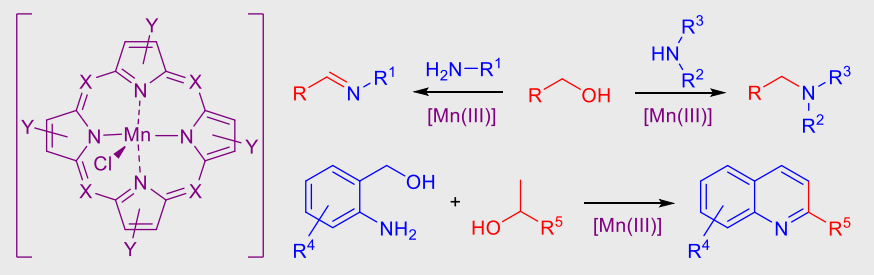

Three times manganese(III): Manganese(III) porphyrin complexes catalyze the dehydrogenative coupling between alcohol and amines to generate imines, tertiary amines and quinolines. Manganese(III) alkoxide and hydride complexes are believed to be the catalytically active species responsible for the hydrogen gas release.
Author(s), Corresponding Author(s)*

\section{Page No. - Page No.}

Title

((Insert TOC Graphic here: max. width: $5.5 \mathrm{~cm}$; max. height: $5.0 \mathrm{~cm}$ ))
K. Azizi, S. Akrami, R. Madsen*

Page No. - Page No.

Manganese(III) Porphyrin-Catalyzed Dehydrogenation of Alcohols to form Imines, Tertiary Amines and Quinolines 